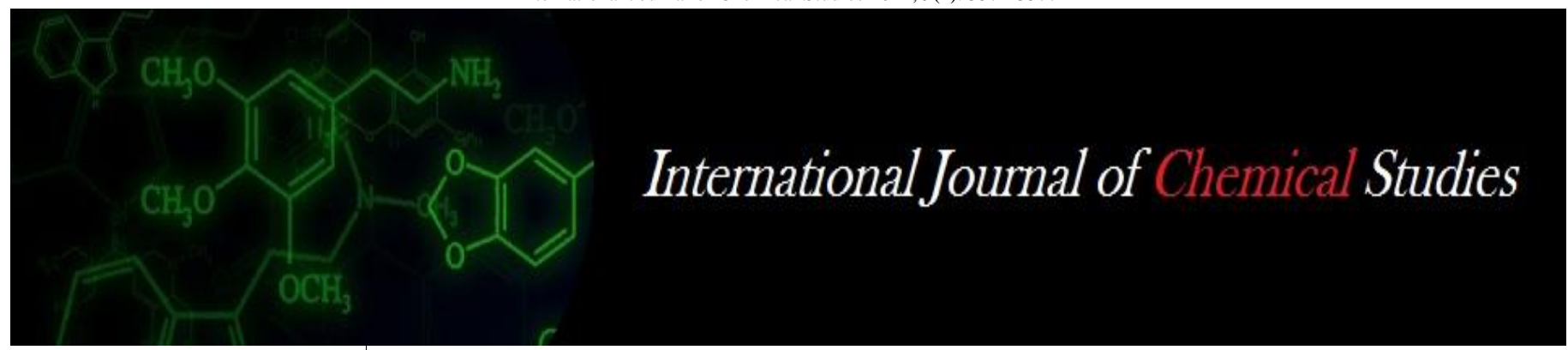

P-ISSN: 2349-8528

E-ISSN: 2321-4902

www.chemijournal.com

IJCS 2021; 9(1): 3574-3577

(C) 2021 IJCS

Received: 12-10-2020

Accepted: 21-12-2020

Sandeep L Badgujar

Vasantrao Naik Marathwada

Krishi Vidyapeeth, Parbhani,

Maharashtra, India

Pawan K Dhoke

Vasantrao Naik Marathwada

Krishi Vidyapeeth, Parbhani,

Maharashtra, India

Manjusha J Shiradkar

Vasantrao Naik Marathwada

Krishi Vidyapeeth, Parbhani,

Maharashtra, India

Sagar Jagdhane

Vasantrao Naik Marathwada

Krishi Vidyapeeth, Parbhani,

Maharashtra, India
Corresponding Author: Sandeep L Badgujar Vasantrao Naik Marathwada Krishi Vidyapeeth, Parbhani, Maharashtra, India

\section{To assess the effectiveness of fungicides against anthracnose disease of chilli in vivo}

\author{
Sandeep L Badgujar, Pawan K Dhoke, Manjusha J Shiradkar and Sagar \\ Jagdhane
}

DOI: https://doi.org/10.22271/chemi.2021.v9.i1ax.11788

\begin{abstract}
Economic losses caused by the disease are mainly attributed to lower fruit quality and marketability which was losses of up to $100 \%$ under congenial environment conditions (Pakdeevaraporn et al., 2005). In India, a calculated loss of from 10-54 per cent has been reported (Lakshmesha et al. 2005) and 10-80 per cent of the marketable yield loss of chilli fruits reported by Than et al., (2008). Hence the present study is aimed to assess the status of anthracnose disease prevailing on chilli so that future strategies for crop protection are devised with a focus on anthracnose disease Average disease intensity recorded during study of field efficacy of fungicides were ranged from 46.63 (Propineb) to 70.23 (Propiconazole). However, significantly maximum average disease intensity was recorded with Propineb fungicide. This was followed by the treatments viz., Copper oxychloride Hexaconazole, Difenconazole, Tricyclazole, Tebuconazole, Azoxystrobin, Carbendazim 12\% + Mancozeb 63\% and Propiconazole.
\end{abstract}

Keywords: Anthracnose, integrated disease management, efficacy of fungicide

\section{Introduction}

Anthracnose of chilli was first reported from new Jersey, USA, described the causal agents as Gloeopsorium piperatum and Colletotrichum nigrum. These taxa were then considered as synonyms of Colletotrichum gloeosporiodes heavy crop losses worldwide. The disease has been reported from many countries including India, United States of America, Nigeria, Bangladesh and Indonesia. Anthracnose disease is a major problem in India and first reported in India from Coimbatore of Madras Presidency. These disease caused by more than one Colletotrichum species including; Colletotrichum acutatum, Colletotrichum capsici, Colletotrichum gloeosporioides and Colletotrichum coccodes. Colletotrichum capsici infection will be higher in the mature stage of chilli plant than in the early stage of plant. The fungus prefers warm humid environment for spreading the anthracnose disease uniformly and effectively.

The pathogen infects all parts of the host plant, including stems and leaves. Lesions on stems and leaves appear as small sunken grayish brown spots with dark margins, further on which development of acervuli in concentric rings could be easily seen. Fruit symptoms initially begins as water soaked lesions that become soft, slightly sunken and become tan. The lesions can cover most of the fruit surface and multiple lesions occurred. The surface of the lesions becomes covered with the wet, gelatinous spores from salmon-coloured fungal fruiting bodies with numerous black spines (setae) and in severe infections, necrotic spots enlarged and coalesced each other into large typical anthracnose lesions leading to premature drying and dropping off of leaves. The fungus survives in the field in plant debris on seed as acervuli and microsclerotia and the secondary spread takes place carry the primary inoculums.

Economic losses caused by the disease are mainly attributed to lower fruit quality and marketability which was losses of up to $100 \%$ under congenial environment conditions. In India, a calculated loss of from 10-54 per cent has been reported and 10-80 per cent of the marketable yield loss of chilli fruits. Hence the present study is aimed to assess the status of anthracnose disease prevailing on chilli so that future strategies for crop protection are devised with a focus on anthracnose disease. Hense, the objective of present study was to assess the effectiveness of fungicides against anthracnose disease of chilli in vivo. 


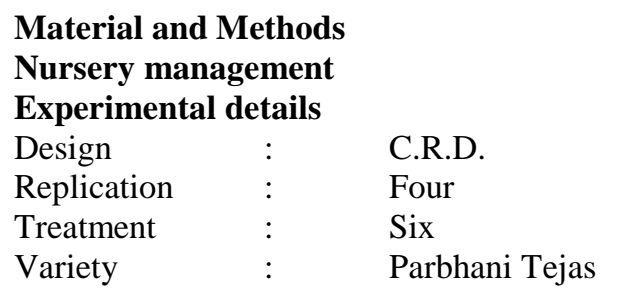

$\begin{array}{cl}\text { Sr. No } & \text { Treatments } \\ \mathrm{T}_{1} & \text { Trichoderma harzianum } \\ \mathrm{T}_{2} & \text { Trichoderma viride } \\ \mathrm{T}_{3} & \text { Carbendazim + Mancozeb } \\ \mathrm{T}_{4} & \text { Carbendazim } \\ \mathrm{T}_{5} & \text { Copper oxychloride } \\ \mathrm{T}_{6} & \text { Control }\end{array}$

Dose
$5 \mathrm{~g} / \mathrm{Kg}$
$5 \mathrm{~g} / \mathrm{Kg}$
$0.2 \%$
$0.2 \%$
$0.2 \%$
FYM $3 \mathrm{~kg} / \mathrm{sqm}$

\section{Observation}

Observations on dieback disease incidence was taken at twenty five days after sowing for die back and fruit rot recorded after 75 DAS. The observations in terms of per cent disease intensity were recorded as per given scale.
Field experiment: The field experiment was conducted during the year (2019-20) at College of Agriculture, Parbhani. Treatments were laid out in the plots $(4.80 \times 3.60 \mathrm{~m})$ arranged in Randomized Rlock Design (RBD) with three replications. Thirty five days old seedlings were planted into the field plots with row to row distance of $60 \mathrm{~cm}$ and plant to plant distance of $60 \mathrm{~cm}$ with a total population of 48 plants per plot. The fungicides were applied at three phenological stages viz. preflowering, fruit set and maturity. The plots were inoculated first with inoculum of Colletotrichum capsici on chilli cultivar and after 72 hours of incubation of pathogen, the respective fungicides were sprayed on chilli plants. Adequate level of moisture maintained under field condition for the proper development of disease.

$\begin{array}{lcl}\text { Details of experiment } & \\ \text { Design } & : & \text { RBD } \\ \text { Replication } & : & \text { Three } \\ \text { Treatments } & : & \text { Nine } \\ \text { Spacing } & : & 60 \times 60 \mathrm{~cm} \\ \text { Variety } & : & \text { Parbhani Tejas } \\ \text { Season } & : & \text { Kharif }\end{array}$

Table 1: Field efficacy of fungicides for management of chilli anthracnose

\begin{tabular}{|c|c|c|c|c|}
\hline Tr. No. & Common Name of Fungicide & Trade name of Fungicide & Group of fungicide & Concentration \\
\hline $\mathrm{T}_{1}$ & Copper oxychloride & Blitox 50WP & Contact & $0.25 \%$ \\
\hline $\mathrm{T}_{2}$ & Carbendazim 12\% + Mancozeb 63\% & SAAF 75WP & Systemic + Contact & $0.25 \%$ \\
\hline $\mathrm{T}_{3}$ & Propineb & Antracol 70WP & Contact & $0.25 \%$ \\
\hline $\mathrm{T}_{4}$ & Hexaconazole & Contaf 5\% EC & Systemic & $0.05 \%$ \\
\hline $\mathrm{T}_{5}$ & Propiconazole & Tilt 25 EC & Systemic & $0.05 \%$ \\
\hline $\mathrm{T}_{6}$ & Difenconazole & Score 25 EC & Systemic & $0.05 \%$ \\
\hline $\mathrm{T}_{7}$ & Tebuconazole & Folicur 25 EC & Systemic & $0.05 \%$ \\
\hline $\mathrm{T}_{8}$ & Azoxystrobin & Amistrar 25 EC & Systemic & $0.05 \%$ \\
\hline $\mathrm{T}_{9}$ & Tricyclazole & Beam 75\%WP & Systemic & $0.05 \%$ \\
\hline
\end{tabular}

\section{Observation}

Data on disease intensity was recorded 15 days after the last spray adopting the formulae. The green yield of chilli from plot of different treatment was taken for calculating the total yield/hectare (tons). All the agronomical practices were followed as per the recommended Package and practices of vegetable crops.

\section{Results and Discussion \\ Integrated disease management strategies Nursery management}

The study of nursery management trials revealed that all the treatments significantly reduced the disease (dieback and fruit rot) as compared to control.

Table 2: Integrated management of anthracnose of chilli. (Pot culture)

\begin{tabular}{|c|c|c|c|c|c|c|}
\hline \multirow{2}{*}{ Tr. No. } & \multirow{2}{*}{ Treatments } & \multirow{2}{*}{ Dose } & \multicolumn{2}{|c|}{ Disease intensity } & \multirow{2}{*}{ Die back control (\%) } & \multirow{2}{*}{ Fruit rot control \% } \\
\cline { 4 - 7 } & & Die back (25 DAT) & Fruit rot (75 DAT) & & \\
\hline $\mathrm{T}_{1}$ & Trichoderma harzianum & $5 \mathrm{~g} / \mathrm{Kg}$ & $17.02(24.36)$ & $24.54(29.69)$ & $45.51(42.42)$ & $39.43(38.89)$ \\
\hline $\mathrm{T}_{2}$ & Trichoderma viride & $5 \mathrm{~g} / \mathrm{Kg}$ & $15.00(22.78)$ & $21.87(27.88)$ & $51.98(46.13)$ & $46.02(42.71)$ \\
\hline $\mathrm{T}_{3}$ & Carbendazim + Mancozeb & $0.2 \%$ & $8.36(16.80)$ & $12.25(20.48)$ & $73.23(58.84)$ & $69.76(56.63)$ \\
\hline $\mathrm{T}_{4}$ & Carbendazim & $0.2 \%$ & $10.23(18.65)$ & $14.32(22.23)$ & $67.25(55.09)$ & $64.65(53.51)$ \\
\hline $\mathrm{T}_{5}$ & Copper oxychloride & $0.2 \%$ & $12.25(20.48)$ & $15.36(23.07)$ & $60.78(51.22)$ & $62.09(51.99)$ \\
\hline $\mathrm{T}_{6}$ & Control & FYM 3kg/sqm & $31.24(33.98)$ & $40.52(39.53)$ & 00.00 & 00.00 \\
\hline & S.E. \pm & 0.57 & 0.57 & 0.52 & 0.49 \\
\hline & C.D. $(\mathrm{P}=0.01)$ & & 1.80 & 1.79 & 1.64 & 1.52 \\
\hline
\end{tabular}

Figures in parenthesis are arc sine transformed value

The most effective treatment was Carbendazim + Mancozeb resulting in least intensity of dieback $(8.36 \%)$ and fruit rot $(12.25 \%)$. This was followed by Carbendazim recording dieback intensity of $10.23 \%$ and fruit rot intensity $(14.32 \%)$. The next efficacious treatment was Copper oxychloride which showed dieback intensity of $12.25 \%$ and fruit rot intensity of $15.36 \%$, respectively. Treatment comprising viz. Trichoderma viride $\mathrm{Tv}-1\left(1 \times 10^{6} \mathrm{spore} / \mathrm{ml}\right)$ and Trichoderma harzianum Th1 (1x107 spore/ml) observed dieback intensity of 15.00 and
17.02 per cent and fruit rot intensity of 21.87 and 24.54 per cent, respectively than control (21.12 and 40.66\%).

The most effective treatment was Carbendazim + Mancozeb which was controls disease upto $73.23 \%$ (dieback disease) and $69.76 \%$ (fruit rot disease). This was followed by treatment of Carbendazim recording dieback control of $67.25 \%$ and fruit rot control upto $(64.65 \%)$ over untreated Nursery pots. The next efficacious treatment was Copper oxychloride which showed dieback control upto $60.78 \%$ and fruit rot control upto $62.09 \%$, respectively. Treatment comprising viz. Trichoderma viride 
and Trichoderma harzianum controls die back disease upto $15.00 \%$ and $17.02 \%$ and fruit rot disease can be controlled over untreated control by $21.87 \%$ and $24.54 \%$, respectively than control $(00.00 \%)$.

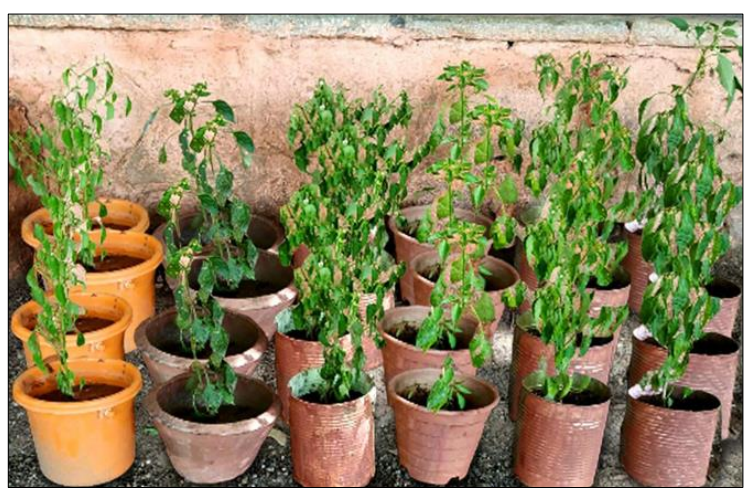

(a)

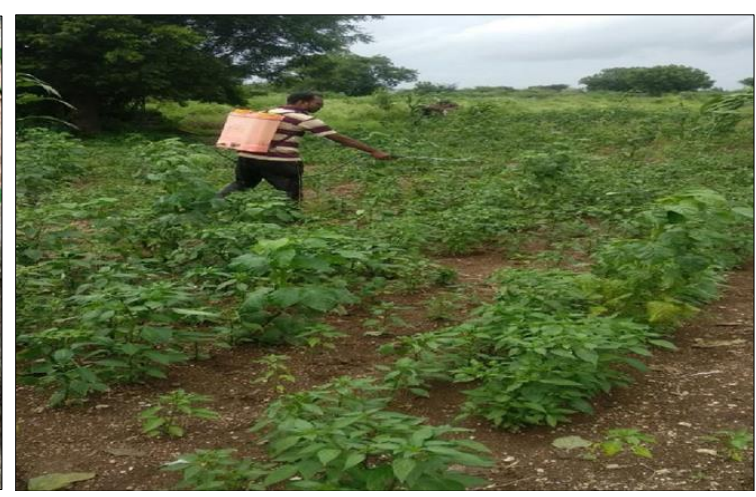

(b)

Fig 1: Integrated management of anthracnose of chilli. (Pot culture)

Field evaluation of fungicides, during the year, 2019-20

All tested nine fungicides tested during the year, 2019-20, were further the management of anthracnose disease in chilli during the year, 2019-20. (PLATE). The results obtained on per cent disease incidence and intensity are presented in the Table.

Table 3: Field efficacy of fungicide for management of chilli anthracnose

\begin{tabular}{|c|c|c|c|c|c|c|c|c|c|}
\hline \multirow{2}{*}{\begin{tabular}{|l|} 
Tr. \\
No. \\
\end{tabular}} & \multirow{2}{*}{ Treatments } & \multirow{2}{*}{ Conc. $(\%)$} & \multicolumn{4}{|c|}{ Percent disease intensity (PDI)* } & \multirow{2}{*}{ Avg. PDI } & \multirow{2}{*}{ - Avg. PDC } & \multirow{2}{*}{$\begin{array}{l}\text { Yeild } \\
\text { q/ha }\end{array}$} \\
\hline & & & Before Spray & After $1^{\text {st }}$ Spray & After $2^{\text {nd }}$ spray & 15 Days After $3^{\text {rd }}$ Spray & & & \\
\hline $\mathrm{T}_{1}$ & Copper oxychloride & $0.25(2.86)$ & $26.76(31.15)$ & $29.47(32.87)$ & $23.42(28.94)$ & $15.13(22.89)$ & $23.69(29.12)$ & 51.39 (45.79) & 10.53 \\
\hline $\mathrm{T}_{2}$ & $\begin{array}{c}\text { Carbendazim } 12 \\
\%+\text { Mancozeb } 63 \%\end{array}$ & $0.25(2.86)$ & $31.52(34.15)$ & $26.52(30.99)$ & $21.52(27.63)$ & $13.37(21.44)$ & $23.23(28.81)$ & 56.08 & 12.32 \\
\hline $\mathrm{T}_{3}$ & Propineb & $0.2(2.86)$ & $28.76(32.43)$ & $28.63(32.97)$ & $25.31(30.20)$ & $19.06(25.88)$ & $25.44(30.29)$ & $48.54(44.16)$ & 11.35 \\
\hline $\mathrm{T}_{4}$ & Hexaconazole & $0.05(1.28)$ & $28.48(32.25)$ & $29.25(32.74)$ & $24.98(29.98)$ & $16.88(24.25)$ & $24.89(29.92)$ & $49.50(44.71)$ & 12.00 \\
\hline $\mathrm{T}_{5}$ & Propiconazoe & $0.05(1.28)$ & $26.54(31.00)$ & $29.35(32.80)$ & $23.11(28.73)$ & $13.91(21.89)$ & $23.22(28.80)$ & 52.39 (46.36) & 12.88 \\
\hline $\mathrm{T}_{6}$ & Difenconazole & $0.05(1.28)$ & $25.78(30.51)$ & $29.88(33.13)$ & $22.13(28.06)$ & $12.38(20.60)$ & $22.54(28.34)$ & $53.50(47.00)$ & 13.54 \\
\hline $\mathrm{T}_{7}$ & Tebuconazole & $0.05(1.28)$ & $21.25(27.45)$ & $31.75(34.29)$ & $23.55(29.03)$ & $13.40(21.47)$ & $22.48((28.30)$ & $50.43(45.24)$ & 14.56 \\
\hline $\mathrm{T}_{8}$ & Azoxystrobin & $0.05(1.28)$ & $21.20(27.41)$ & $26.85(31.20)$ & $18.15(25.21)$ & $07.70(16.11)$ & $18.47(25.45)$ & $61.35(51.56)$ & 16.21 \\
\hline $\mathrm{T}_{9}$ & Tricyclazole & $0.05(1.28)$ & $18.33(25.34)$ & $27.00(31.30)$ & $18.25(25.29)$ & $12.25(20.48)$ & $18.25(25.29)$ & $58.60(49.95)$ & 16.32 \\
\hline & S.E. \pm & & 0.012 & & & 0.007 & & 0.019 & \\
\hline & C.D. $(\mathrm{P}=0.01)$ & & 0.035 & & & 0.021 & & 0.057 & \\
\hline
\end{tabular}

Disease incidence: Results (Table and Fig) revealed that all the treatment sprays significantly influenced the percentage anthracnose disease incidence of chilli. The disease was found to appear about 35 to 40 days after transplanting of the crop and its incidence at first appearance was ranged from 18.33 to 31.52 per cent, which increased steadily upto second spray treatment and subsequently decreased thereafter second spray treatment.

After first spraying, the disease incidence was ranged from $26.52 \%$ (Carbendazim 12\% + Mancozeb 63\%) to $31.75 \%$ (Tebuconazole) as against $41.25 \%$ in unsprayed control and all the treatments were found significantly superior over unsprayed control. However, significantly least

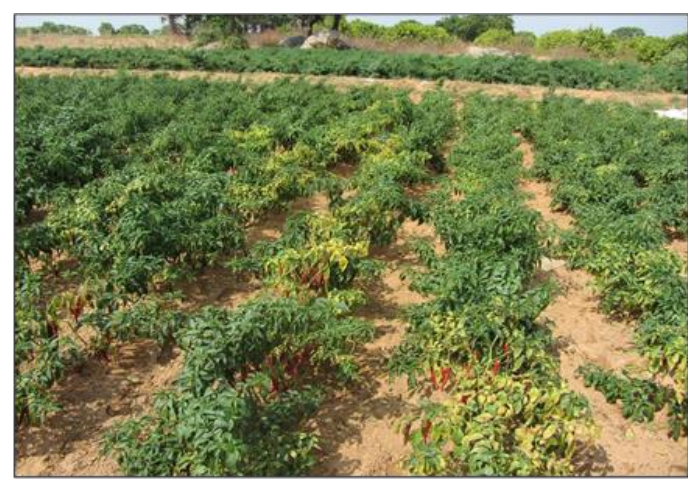

(a)

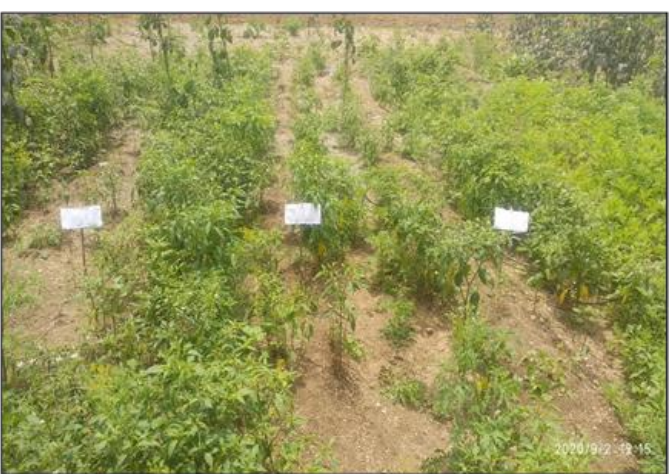

(b)

Plate 1: Field efficacy of fungicide for management of chilli anthracnose

Disease incidence was recorded with the fungicides Carbendazim $12 \%$ + Mancozeb $63 \%$ (26.52\%) followed by Azoxystrobin (26.85\%), Tricyclazole (27.00\%), Propineb (28.63\%), Hexaconazole (29.25\%), Propiconazole (29.35\%),
Copper oxychloride (29.47\%), Difenconazole (29.88\%) while minimum disease intensity recorded with Tebuconazole $(31.75 \%)$.

After second spraying, the disease incidence was ranged from 
$18.15 \%$ (Azoxystrobin) to $25.31 \%$ (Propineb) as against 47.96 per cent in unsprayed control, and all the treatments were found significantly superior over unsprayed control. However, significantly least disease incidence was recorded with the fungicides Azoxystrobin (18.15\%), Tricyclazole (18.25\%), Carbendazim 12\% + Mancozeb 63\% (21.52\%), Difenconazole $(22.13 \%)$, Propiconazole (23.11\%) Copper oxychloride $(23.42 \%)$ followed by Tebuconazole $(23.55 \%)$ and Hexaconazole $(24.98 \%)$. While minimum disease intensity recorded with Propineb (25.31\%).

After third spraying, the disease incidence was ranged from $7.70 \%$ (Azoxystrobin) to $19.06 \%$ (Propineb) as against $59.25 \%$ in unsprayed control, and all the treatments were found significantly superior over unsprayed control. However, significantly least disease incidence was recorded with the fungicides Azoxystrobin (7.70\%), Tricyclazole (12.25\%), Difenconazole (12.38\%), Carbendazim12\% + Mancozeb $63 \%$ (13.37\%), followed by Tebuconazole (13.40), Propiconazole (13.91\%), Copper oxychloride (15.13\%), Hexaconazole $(16.88 \%)$, while minimum disease intensity recorded with Propineb (17.36\%).

Average disease incidence recorded with all the spray treatments were ranged from $18.25 \%$ (Tricyclazole) to $25.44 \%$ (Propineb). However, significantly least average disease incidence $(18.25 \%)$ was recorded with Tricyclazole. This was followed by the treatments viz. Azoxystrobin (18.47\%), Tebuconazole (22.48\%), Difenconazole (22.54\%), Propiconazole (23.22\%), Carbendazim $12 \%+$ Mancozeb $63 \%$ (23.23\%), Copper oxychloride (23.69\%), Hexaconazole $(24.89 \%)$ with average disease incidence was recorded with Propineb (26.78\%); all of which were at par.

The table revealed highest yield (16.32 q/ha) was recorded with Tricyclazole followed by $16.21 \mathrm{q} / \mathrm{ha}$ with fungicide Azostrobin. While as lowest yield (11.35 q/ha) was recorded with Propineb. Fungicide viz Tebuconazole, Difenoconazole, Propiconazole, Carbendazim 12\% + Mancozeb, Copper oxychloride, Hexaconazole were recorded 14.56, 13.54, 12.88, 12.32 and $12.00 \mathrm{q} / \mathrm{ha}$ yield respectively which were significantly superior to control.

The present results confirms results of evaluated three fungicides viz., Carbendazim, Hexaconazole and Propiconazole against Colletotrichum capsici, causing anthracnose or fruit rot of chilli and reported least per cent disease intensity with Propiconazole $(0.1 \%)$ with maximum yield of red chilli and highest cost: benefit ratio.

\section{Summary and Conclusions}

- Integrated management for die back and fruit of chilli, nursery trials revealed that most effective treatment was Carbendazim + Mancozeb recorded least disease intensity. Order of effective treatments for control of dieback and fruit rot infeststion was Carbendazim followed by Copper oxychloride, Trichoderma viride and Trichoderma harzianum respectively.

- Average disease incidence recorded after three sprays, during study of field efficacy of nine fungicides, for control of chilli anthracnose, were ranged from $17.02 \%$ (Carbendazim $12 \%+$ Mancozeb $63 \%$ ) to $26.78 \%$ (Propineb). Order of effective treatments was Azoxystrobin, Propiconazole, Tricyclazole, Hexaconazole, Tebuconazole, Copper oxychloride, Difenconazole, and Propineb respectively.

- Average disease intensity recorded during study of field efficacy of fungicides were ranged from 46.63 (Propineb) to 70.23 (Propiconazole). However, significantly maximum average disease intensity was recorded with Propineb fungicide. This was followed by the treatments viz., Copper oxychloride Hexaconazole, Difenconazole, Tricyclazole, Tebuconazole, Azoxystrobin, Carbendazim $12 \%+$ Mancozeb $63 \%$ and Propiconazole.

\section{References}

1. Chirame BB, Padule DN. Effect of Trichoderma spp. on the growth of Colletotrichum capsici isolated from cotton seeds. Agric. Sci. Digest 2005;25(3):216.

2. Datar VV. Pathogenicity and effect of temperature on six fungi causing fruit rot of chilli. Indian J Mycol. Pl. Pathol 1995;25(3):195-197.

3. Datar VV, Sontakke MB, Purandare NP, Shinde NN. Fungicidal control of anthracnose of chilli. Indian J Mycol. Pl. Pathol 1990;20(2):156-156.

4. Deeksha J, Tripathi HS. Perpetuation of Colletotrichum capsici in infected seeds and crop debris of urdbean. $\mathbf{J}$ Mycol. Pl. Path 2002;32(1):28-30.

5. Dennis KL, Webster J. Antagonistic properties of species group of Trichoderma and hyphal interaction. Trans. British Mycol. Soc 1971;57:363-396.

6. Ehenezar EG, Alice D. Field evaluations of fungicides against fruit rot and die-back of chillies. Indian J Pl. Prot 1996;24(1-2):50-52.

7. Ekbote SD. Studies on anthracnose of mango (Mangifera indica L.) caused by Colletotrichum gloeosporoioides (Penz) Penz and Sacc. M. Sc. (Agri.) Thesis, Univ. Agric. Sci., Dharwad, Karnataka, India 1994. 